\title{
Earth Hour in Vietnam: a perspective from the electricity industry
}

Vuong Quan-Hoang, La Viet-Phuong, Vuong Thu-Trang, Ho Manh-Toan

$$
\text { Apr 21, } 2020
$$

Nature: Behavioural \& Social Sciences

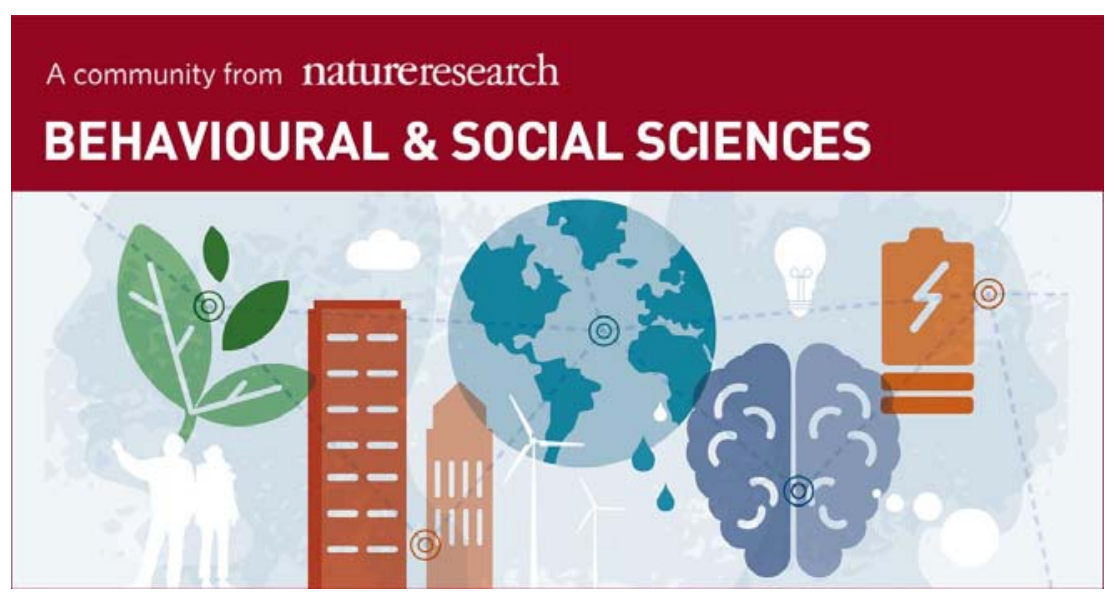

https://socialsciences.nature.com/posts/66561-earth-hour-in-vietnam-a-perspectivefrom-the-electricity-industry 
A community from nature research

$\equiv$ BEHAVIOURAL \&

\section{Earth Hour in Vietnam: a perspective from the electricity industry}

Earth Hour is one of the most popular environmental events in Vietnam. However, looking at the rise in electricity consumption in the country, it is impossible to feel its impact.

4. Ho Manh Toan Apr 21,2020 听 2 的 1

Authors: Vuong Quan-Hoang 1, La Viet-Phuong 1, Vuong Thu-Trang 2, Ho ManhToan 1

1) Centre for Interdisciplinary Social Research, Phenikaa University, Ha Noi, Viet Nam

2) Sciences Po Paris, Paris, France

In 2009, the World Wide Fund for Nature (WWF) launched the first Earth Hour campaign in Vietnam. The campaign has become an annual event and receives enthusiastic participation from Vietnamese people. The Vietnamese government particularly the Ministry of Industry and Trade and the Ministry of Natural Resources and Environment - also helps with the organization of the campaign. This year, the 
National Power Dispatch Centre estimated that Vietnam saved 436,000 kilowatthours (kWh) of electricity, equivalent to VND 812.9 million (approx. US\$34,928) during one hour of the event.

Details of estimated saved kWh of electricity and their economic values are collected in the table below:

\begin{tabular}{|c|c|c|c|}
\hline Year & kWh saved & Estimated economic value & Source \\
\hline 2020 & 436,000 & VND 812.9 million (US\$34,928) & {$[1]$} \\
\hline 2019 & 492,000 & VND 917 million (US\$39,500) & {$[2]$} \\
\hline 2018 & 485,000 & VND 834 million (US\$36,612) & {$[3]$} \\
\hline 2017 & 471,000 & VND 764 million (US\$33,616) & {$[4]$} \\
\hline 2016 & 451,000 & VND 731.5 million (US\$31,238) & {$[5]$} \\
\hline 2015 & 520,000 & VND 850 million (US\$39,100) & {$[6]$} \\
\hline 2014 & 431,000 & VND 650 million (US\$27,740) & {$[7]$} \\
\hline 2013 & 401,000 & VND 576 million (US\$24,582) & {$[8]$} \\
\hline 2012 & 546,000 & VND 712 million (US\$30,386) & {$[9]$} \\
\hline 2011 & 400,000 & VND 500 million (US\$21,338) & {$[9]$} \\
\hline 2010 & 500,000 & VND 450 million (US\$19,204) & {$[9]$} \\
\hline 2009 & 140,000 & VND 126 million (US\$5,380) & {$[9]$} \\
\hline
\end{tabular}


Table 1. Estimation of saved $\mathrm{kWh}$ during Earth Hour events in Vietnam and their economic values.

According to the estimation, from 2010 until 2020, Earth Hour in Vietnam has helped to save about 466,636 kWh per year on average, which translated to roughly VND 6 billion (US\$272,266). During the first year of the campaign in Vietnam, 2009, only six provinces participated; thus, only about 140,000 kWh of electricity was saved. However, in reality, the total amount of electric consumption has been rising continuously since 1990 (See Figure 1).

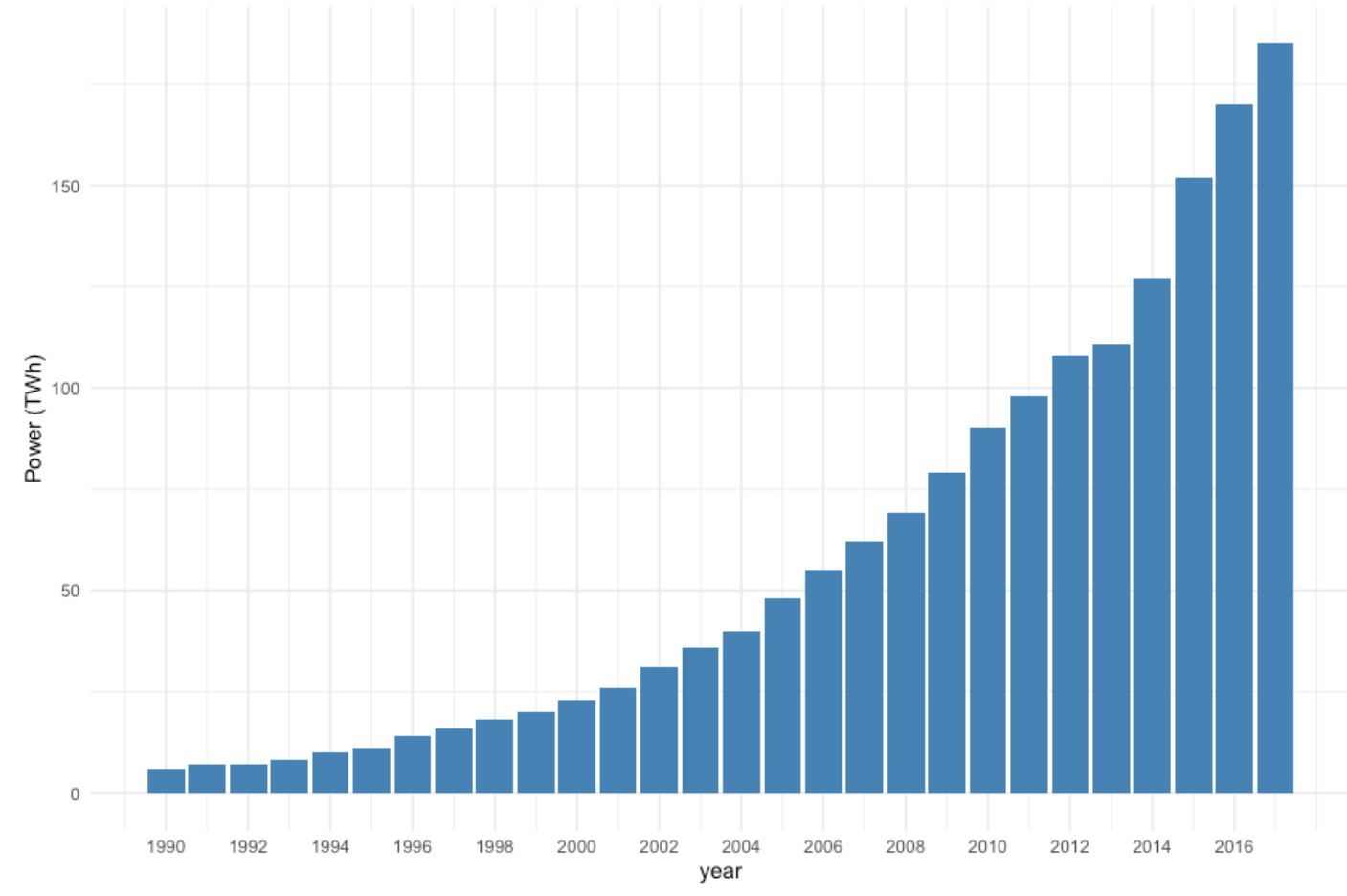

Figure 1. The total amount of electric consumption in Vietnam from 1990 until 2017. (Source: IEA)

In the 28-year period depicted in Fig. 1, Vietnam had multiplied its electric consumption by 30 times, from only 6 Terawatt hours (TWh) in 1990 to 185 TWh in 2017. From 2009 - the first Earth Hour event in Vietnam - to 2017, the figure had doubled. Furthermore, let's take a look at the revenue of three big power generation corporations in Vietnam: Power Generation Joint Stock Corporations, or Genco, 1, 2, and 3 (Figure 2), who occupies roughly $58 \%$ of the total capacity of the electricity 
industry in Vietnam. The total revenue of all three companies rose from a total of US\$2,4 million in 2015 to US\$3,6 million in 2017. Genco 1's revenue showed a 3.5-fold increase in the 2015-2018 period.

One may have now asked one's self: "What is the point with this small amount of saved consumption?" True. The amount is negligible, in economic terms, on a national scale. But it helps to raise public awareness on a much bigger and difficult-to-solve problem. That is the problem of destroying our quintessential ecosystems in exchange for some temporary living comfort.The next lines will tell more in detail.

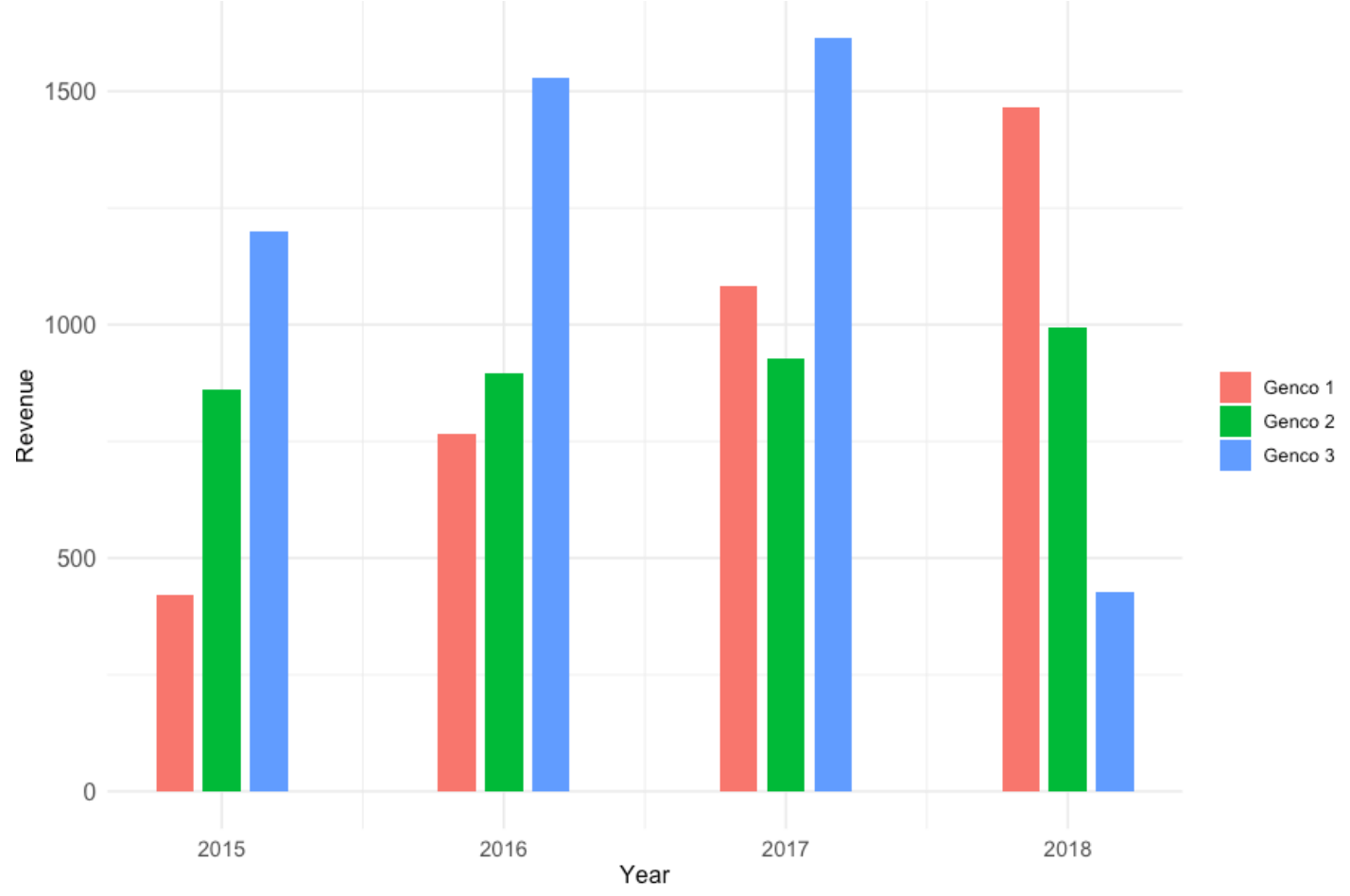

Figure 2. The revenue (in USD) of Power Generation Joint Stock Corporations (Genco) 1, 2, and 3 from 2015 until 2018. (Source: Corporate financial reports)

Most electric power companies in Vietnam utilize hydropower (which requires dams) or thermal power (which burns fossil fuel or natural gas). Corresponding with the total amount of electric consumption in Vietnam, Fig. 3 suggested the rise of power generation from these three sources. From 2009 to 2017, electricity from hydropower sources jumped from 29,981 Gigawatt-hour (GWh) to 88,982 GWh. Coal and natural gas also saw similar rises in the same period. However, outputs from both sources 
have shown a downward trend since 2016.

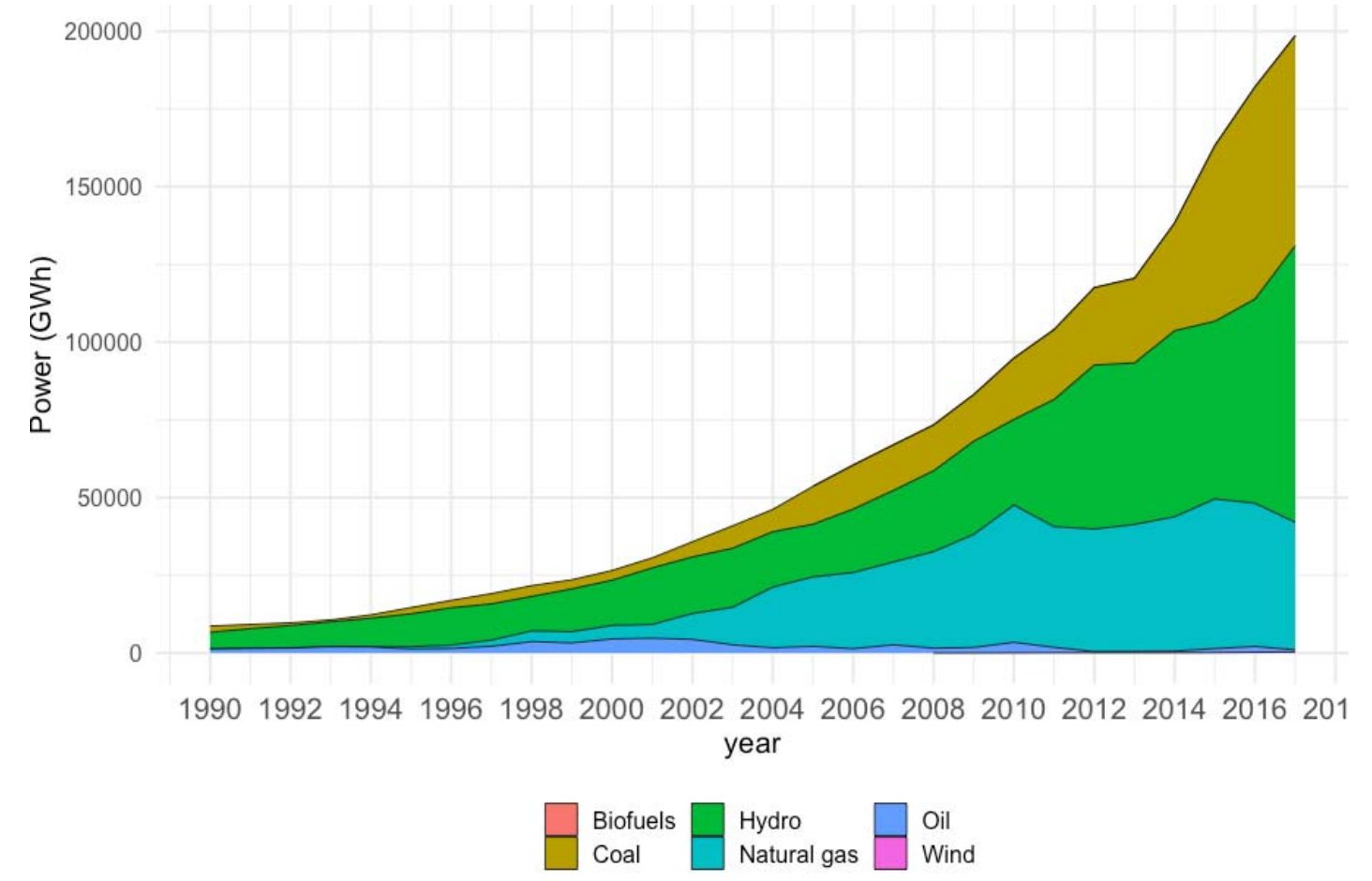

Figure 3. The sources of electricity in Vietnam from 1990 until 2017. (Source: IEA)

The rise in electricity consumption in Vietnam owes itself to the growth of the Vietnamese economy. In the $2000-2020$ period, the average growth rate of Vietnam is $6.51 \%$. In the last two years, Vietnam has maintained its growth rate at $7 \%$, even higher than China. Subsequently, the demand for electricity is expected to double in the next ten years, along with heavy pollution [10].

While hydroelectric plants are less detrimental to the environment than thermal plants, they have impacted the biodiversity and natural habitat in their surrounding areas. Investigative reports have shown that hydropower plants, especially small ones, caused severe drought [11]. Moreover, forests were also cut down to make space for new power plants.

In 2019, we had the opportunity to assist the International Union for Conservation of Nature (IUCN) Vietnam in an initiative called Vietnam Business for Environment (VB4E). The main goal of the initiative is to engage Vietnamese businesses in 
environmental and biodiversity conservation issues. Through tracking all major environment-related events and stakeholders in Vietnam, we were able to identify main problems relating to the relationship between Vietnam businesses and environmental conservation.

The findings, which are currently under peer review, suggest the reasons for Vietnam businesses to engage in pro-environmental behaviors are practical and self-serving, i.e., profitability or public image [12]. Companies in the energy industry also involved in 6 events of severe environmental damage; three companies out of which produce thermal power. Moreover, there is a high degree of involvement by governmental agencies in helping businesses bypassing environmental guidelines.

Through this post, we want to introduce a different perspective to look at a proenvironment event such as Earth Hour or Earth Day. Earth Hour has been widely accepted as a meaningful pro-environment event in Vietnam. However, its true impact is still hidden, much like the hidden environmental cost of Vietnam's exponential electric consumption and production. Switching off the light needs to surpass its symbolic significance as well as its restrained benefits. Earth Hour needs to become the pretext to bring attention to the tensions between environment conservation and economic growth - and, more importantly, on the level of businesses, between insistent profit-making and actions detrimental to the environment. Earth Hour is in and of itself reflecting our genuine effort to avoid policy failures in protecting the health of Earth [13].

Poster Image: Hoa Binh Hydroelectric Dam - one of the largest hydroelectric dams in Vietnam. Source: Wikimedia Commons.

\section{References}

[1] VNS. (March 29, 2020). Earth Hour in Vietnam: We just saved over VND800 million worth of electricity. Vietnam Insider. Retrieved from https://vietnaminsider.vn/in-v... (Accessed April 21, 2020). 
[2] VNA. (April 01, 2019). Over 910 million VND saved during Earth Hour in Viet Nam. Da Nang Today. Retrieved from https://www.baodanang.vn/engli... (Accessed April 21, 2020).

[3] VNA. (March 27, 2018). 485,000 kWh of electricity saved during Earth Hour 2018. VTV News. Retrieved from https://english.vtv.vn/news/48... (Accessed April 21, 2020).

[4] VNS. (March 27, 2017). Earth Hour helps save power. Viet Nam News. Retrieved from https://vietnamnews.vn/society/373567/earth-hour-helps-save-power.html (Accessed April 21, 2020).

[5] Thao, T. (March 21, 2016). Earth Hour 2016: 451,000 kWh of electricity saved nationwide during 1 hour of the lights-off event. VNEEC. Retrieved from http://vneec.gov.vn/tin-tuc/activity-news/t24710/earth-hour-2016-451-000-kwhof-electricity-saved-nationwide-during-1-hour-of-the-lights-off-event.html (Accessed April 21, 2020).

[6] NDO. (March 29, 2015). Vietnam saves 520,000kWh of electricity during Earth Hour. Nhan Dan. Retrieved from https://en.nhandan.com.vn/society/item/3232002vietnam-saves-520-000kwh-of-electricity-during-earth-hour.html (Accessed April 21, 2020).

[7] VEN. (April 10, 2014). 431,000 kWh saved from 2014 Earth Hour. Vietnam Energy Online. Retrieved from http://nangluongvietnam.vn/new... (Accessed April 21, 2020).

[8] My, L. (March 28, 2013). Vietnam saves 401 MW during 2013 Earth Hour. VNEEC. Retrieved from http://vneec.gov.vn/tin-tuc/ac... (Accessed April 21, 2020).

[9] EVN. (April 01, 2012). Giờ trái đất 2012: Tiết kiệm 546 nghìn kWh [Earth Hour 2012: $546,000 \mathrm{kWh}$ was saved]. EVN. Retrieved from https://www.evn.com.vn/d6/news... (Accessed April 21, 2020).

[10] Vu, K., \& Gloystein, H. (May 24, 2019). In Vietnam's booming energy sector, coal 
reigns, but renewables play catch-up. Reuters. Retrieved from https://reut.rs /3cD9URJ (Accessed April 21, 2020).

[11] Nguyen, T., Nguyen, N., \& Ha, P. (October 15, 2017). Confessions of a hydropower calamity in Vietnam. VnExpress. Retrieved from https://e.vnexpress.net/projects /confessions-of-a-hydropower-calamity-in-vietnam-3655314/index.html (Accessed April 21, 2020).

[12] Vuong, Q. H., La, V. P., Nguyen, T. H. K, Ho, T. M., Vuong, T. T., \& Ho, M. T. (2020, April 20). Identifying the moral-practical gaps in corporate social responsibility missions of Vietnamese firms: an event-based analysis of sustainability feasibility. OSF, DOI: osf.io/mcdq4

[13] Vuong, Q. H. (2018). The (ir)rational consideration of the cost of science in transition economies. Nature Human Behaviour, 2(1), 5, DOI: 10.1038/s41562-017-0281-4. URL: https://www.nature.com/articles /s41562-017-0281-4.

\section{Ho Manh Toan}

\section{Comments}

